Open Access

\title{
Organising for innovation in regional innovation systems: from fragmented innovation ecosystems to the joint aim for competitiveness of offshore wind energy
}

Tove Brink

Correspondence: tbr@sam.sdu.dk Department of Sociology, Environmental and Business Economics, University of Southern Denmark, Niels Bohrs Vej 9, 6700 Esbjerg, Denmark

\begin{abstract}
The research in this paper reveals how organising the innovation ecosystem can enable the achievement of the aim for innovation and competitiveness. The research was conducted from June 2014 to May 2015 using a qualitative deductive approach among operation \& maintenance (O\&M) actors in offshore wind parks. The research contains a focus group interview with 11 companies, 20 individual interviews and a preliminary seminar on the findings with 60 participants.

The findings reveal the triple helix framing as being useful for the offshore wind ecosystem to enable innovation. The findings highlight the need for transnational flexible alignment of regulations and procedures with a focus between the helixes on timeliness, transparency and open collaboration practices. Additionally, collaboration with SMEs can enable complementary dynamic knowledge creation in conjunction with university research and educational training. A contribution is made to application of the triple helix notion to enable innovation in offshore wind ecosystems.
\end{abstract}




\section{Résumé}

Cet article révèle comment l'organisation d'un écosystème d'innovation peut permettre d'atteindre l'objectif d'innovation et de compétitivité. La recherche a été menée de Juin 2014 à Mars 2015 par une approche qualitative déductive sur les acteurs d'opération et de maintenance (O\&M) dans des parcs éoliens offshore. La recherche porte sur un focus group de 11 entreprises, 20 personnes interviewées et un séminaire préliminaire sur les résultats avec 60 participants.

Les résultats révèlent que le cadre de la Triple Hélice est utile pour les innovations au sein de l'écosystème des entreprises éoliennes offshore. Ils soulignent la nécessité d'un alignement transnational flexible des procédures et règlements avec un accent sur la rapidité, la transparence et les pratiques ouvertes de collaboration entre les hélices. En outre, la collaboration avec les PME peut permettre la création de savoir dynamique complémentaire en relation avec la recherche et de formation à l'université. L'article se veut une contribution à l'application de la notion de Triple Hélice pour permettre l'innovation dans les écosystèmes des entreprises éoliennes offshore.

\section{Resumo}

Este artigo revela a pesquisa sobre como a organização do ecossistema de inovação pode permitir o alcance do objetivo de inovação e competitividade.

A pesquisa foi conduzida de junho de 2014 a maio de 2015 usando uma abordagem qualitativa dedutiva entre atores de operação e de manutenção $(\mathrm{O} \& \mathrm{M})$ em parques eólicos offshore. A pesquisa contém uma entrevista com grupo focal com 11 empresas, 20 entrevistas individuais e um seminário preliminar sobre os resultados com 60 participantes.

Os resultados revelam que a estrutura da hélice triplice é útil para possibilitar a inovação do ecossistema eólico offshore.

Os resultados destacam a necessidade de um alinhamento transnacional flexível de regulamentos e procedimentos com um foco entre as hélices sobre oportunidade, transparência e práticas de colaboração aberta. Além disso, a colaboração com PMEs pode permitir a criação de conhecimento dinâmico complementar em conjunto com pesquisas universitárias e a formação educacional. A contribuição é feita com a aplicação da noção de hélice triplice para permitir a inovação em ecossistemas eólicos offshore.

\section{Аннотация}

Исследование, представленное в данной работе, посвящено тому, как организация инновационной экосистемы может способствовать достижению цели в вопросах управления инновациями и конкурентоспособностью. Исследование проводилось в период с июня 2014 по май 2015 с использованием качественного дедуктивного подхода среди производственных и ремонтных организаций (О\&M) в прибрежных ветряных электростанциях. Исследование содержит интервью в фокус-группах среди 11 компаний, 20 независимых интервью и промежуточный семинар, в ходе которого результаты исследования были представлены 60 участникам. В ходе исследования подтвердилось, что модель тройной спирали является эффективной в контексте создания экосистемы ветряных электростанций и стимулирования инноваций. Результаты указывают на необходимость внедрения (Continued on next page) 
(Continued from previous page)

транснациональной гибкой цепи регуляторов и процедур с акцентом на своевременности, прозрачности и практиках открытого сотрудничества. Кроме того, партнерство с малыми и средними компаниями (SMES) может способствовать комплиментарному динамическому созданию знаний в партнерстве с университетскими исследованиями и образовательными семинарами. Вклад исследования значим с позиций применения знаний о тройной спирали для стимулирования инноваций в экосистеме прибрежных электростанций.

\section{Resumen}

La investigación en este documento revela cómo la organización del ecosistema de innovación puede permitir el logro conjunto de innovación y de competitividad. La investigación se llevó a cabo entre junio del 2014 y mayo del 2015 utilizando un enfoque deductivo cualitativo entre actores de operación y mantenimiento (O\&M) en parques eólicos marinos. La investigación contiene una entrevista de grupo focal con 11 empresas, 20 entrevistas individuales y un seminario preliminar sobre los hallazgos con 60 participantes.

El estudio muestra que la estructura de la Triple Hélice permite la innovación en el ecosistema de energía eólica. Los hallazgos destacan la necesidad de una alineación flexible transnacional de regulaciones y procedimientos con un enfoque entre las hélices sobre la puntualidad, la transparencia y las prácticas de colaboración abierta. Además, la colaboración con las PYMES puede permitir la creación complementaria de conocimientos dinámicos junto con la investigación universitaria y la formación educativa. Este artículo es una contribución a los estudios de la Triple Hélice en el caso de innovación en ecosistemas eólicos marinos.

\section{Multilingual abstract}

Please see Additional file 1 for translation of the abstract into Arabic.

\section{Introduction}

For several years, politicians have proclaimed the need for the environmentally friendly offshore wind energy to become economically competitive with other energy sources (World Energy Council (WEC) 2013). Offshore wind energy is beneficial because it alleviates the onshore challenges felt by people living near wind turbines. Additionally, wind is generally stronger on the sea than onshore (IRENA 2016). The urge for collaboration was strengthened in June 2016 by the Global Wind Energy Council (GWEC) Declaration, which was signed by 12 major actors in the offshore wind industry with the aim to reduce Levelized Cost of Energy (LCOE) to 80 EUR/ MWh in 2025. Recently, a tender on an offshore wind park was won by Vattenfall at the surprising rate of $49.9 \mathrm{EUR} / \mathrm{MWh}$ (Vattenfall press release 2016) strengthening the aim even further.

Offshore wind parks are ecosystems situated across national borders, as they are placed in international waters and contain stakeholders from various countries both across the North Sea and beyond. In Porter's (1998) notion, he distinguishes between the terms 'cluster' and 'network' by referring to clusters as geographically 
closely located organisations, while networks can be located anywhere. In innovation theory, the notion of 'ecosystem' networks describes the range of 'value creating interactions and relationships between sets of interconnected organisations' (Autio and Thomas 2014). This concept is thus independent of location and provides fresh ways of thinking about specialisation, co-evolution and cocreation of value (Adner and Kapoor 2010). The interconnected ecosystem nature of the offshore wind park industry is stressed through the definition of LCOE, which briefly is noted as 'the sum of the discounted lifetime generation costs $(€)$ divided by the sum of discounted lifetime electricity output (MWh)' (Crown estate 2012). In the offshore wind park, LCOE is based on the production performance of electricity from the offshore wind park and the related costs regarding construction, production, installation and O\&M activities. Many different stakeholders and organisations are present in the offshore wind park innovation ecosystem (DWIA 2012). It is essential for offshore wind energy to become competitive through innovation, as offshore wind typically has 2-3 times higher LCOE than traditional energy resources (OpenEI 2016). In the period from 2010 to 2014, LCOE decreased by $11 \%$ primarily due to the 'industry's early adoption of larger turbines' (Catapult 2015; p. 4). This means that mainly technical efforts have succeeded. Until now, limited activity has been devoted to organising ecosystem collaboration. This is shown in the 'long-term research challenges' announced by the European Academy of Wind Energy (EAWE 2016), where the need for organising the innovation ecosystem is only briefly mentioned. Knowledge is thus underdeveloped regarding the research question in this paper: How can organising the innovation ecosystem enable the achievement of the aim for innovation and competitiveness of offshore wind energy?

Governments have declared and taken actions to support the goal of achieving sustainable renewable energy. This was announced in the EU 'commission priority' regarding the EU 'Energy Union', which states the following, 'The Energy Union means making energy more secure, affordable and sustainable'; this view is enhanced in the overall political statement: 'New technological and renewed infrastructure will cut household bills and create new jobs and skills, as companies expand exports and boost growth' (European Commission, Fact Sheet 2015). It can thus be seen that, through EU activities, governments are very focused on the renewable sustainable energy issue. Globally, the UN resolution (2015) does the same. Research programmes have been launched and financed in the EU horizon 2020 for universities to support the governmental aim through enhanced knowledge creation. A triple helix context, as defined by Etzkowitz and Leydesdorff (2000), is thus present for organising the aim of governments, universities and offshore wind industry for joint innovation collaboration. The research is financed by the Region of South Denmark and administered by the Danish Wind Industry Association and offshoreenergy.dk. None of these parties have any impact on the research and article written.

\section{Organisation of the paper}

The outline of the paper is as follows: First, the theoretical framing of the paper will be elaborated for positioning of the paper in relation to existing knowledge. Then, the 
methodology of the research will be described for understanding the data and analyses in the research conducted. Additionally, information in general about the offshore wind network will be revealed. Next, the findings will be highlighted, analysed, discussed and summarised in a triple helix model to enable innovation in the offshore ecosystems. Finally, the conclusion and recommendations will be presented.

\section{Theoretical framing}

The long-term lifetime context of approximately 15-25 years for offshore wind parks creates an institutional framework for innovation among triple helix parties of industry, university and government as noted by Etzkowitz and Leydesdorff (2000). The three different actors in the triple helix concept typically have different interests (Leydesdorff and Meyer 2006). Universities are interested in 'novelty production' of knowledge. Industry enterprises are interested in 'wealth generation' within business contexts, which means better economic performance of operations and enterprises. Governmental bodies are interested in the 'public well-being' offered by renewable energy in society. In the offshore wind energy context, governmental bodies provide subsidies to offshore wind parks for support of investments in the area. The amount of subsidies is large (WES 2013) and therefore often subject for public debate generating political requests for 'local content' in wind parks, which means employing local labour and local suppliers for installation and O\&M activities. Theory related to the triple helix notion emphasises the need for blurred boundaries between the three participant roles. The blurred boundaries enhance opportunities to find commonalities in joint organisational learning activities to enable innovation. Moreover, the need for a continuous balance between the integration and differentiation of activities needs to be recursive and reflective to find the balance to enable innovation among the participants (Etzkowitz and Leydesdorff 2000). The many different interests pursued by actors in the triple helix notion (Etzkowitz and Viale 2010; Leydesdorff 2012; Etzkowitz 2014) can thus provide a useful framing for the offshore wind energy innovation ecosystem. Smalland medium-sized enterprises (SMEs) are additionally important actors because they can contribute with enhanced innovation (Brink and Madsen 2016) within offshore wind parks. SMEs can provide a 'dynamic complementarity' (Rothwell and Dodgson 1991; Dodgson 2014) through flexibility and responsiveness to new market requirements and application in ways larger enterprises cannot.

The ecosystem network notion extends the concept of the value chain to that of a system that includes any organisation that contributes to the shared offerings (Autio and Thomas 2014). The loosely coupled organising of innovation ecosystems means that no clear governance structure is present. This can result in only incremental innovations between a limited number of organisations and sub-optimisation (Autio and Thomas 2014). However, by developing a deeper understanding of the characteristics of their own ecosystem dynamics over time, actors can create the position and the direction of their organisations to pursue the overall aim within the ecosystem (Malerba and Adams 2014). Focus on open dialogue and organisational learning on the joint aim can enable innovation initiatives to pursue the overall aim. Steiber and Alänge (2015) elaborate the OECD/Eurostat (2005) definition on organisational innovation to 'improve a firm's competitiveness'. They emphasise the need to strengthen the ambidextrous capacity of both exploration and exploitation (March 1991) by simultaneous development 
of radically new innovations and development of the revenue generation from existing processes, products and services. This forms an 'organisational improvement trajectory' (Steiber and Alänge 2015; 12), which is claimed to exist on all organisational levels. In this trajectory, organisational innovations are diffused between enterprises and reinvented. In particular, 'less focus on formal processes', 'employee empowerment,' 'selforganisation' and the ability to 'continually innovate' are stressed as necessary antecedents to enable innovation in ecosystems (Steiber and Alänge 2015).

Based on the previous literature review, proposition one can be formulated as follows:

Proposition 1: the collaboration of triple helix actors including SMEs in the offshore wind innovation ecosystem can use both exploration and exploitation to enhance innovation The framing of the proposition is concisely illustrated in Fig. 1.

Figure 1 shows the triple helix frame enhanced with SMEs and blurred boundary spaces to support the duality of exploration and exploitation for the innovation trajectory in the ecosystem.

\section{Method}

The research is based on qualitative deductive semi-structured interviews conducted between June 2014 and May 2015 with actors operating within O\&M activities in offshore wind parks. In the beginning of the qualitative research, a focus group interview was conducted with 11 participants who were invited due to their different roles in O\&M activities within offshore wind parks. The O\&M area has never before been a target for research on innovation and the reduction of LCOE. Therefore, a focus group approach was selected for preparation of an interview guide to address the essential issues later in the more thorough individual interviews for deductive analyses. The participants in the focus group interview revealed challenges and phenomena in terms of a broad spectrum of offshore O\&M activities. The 11 participants in the semi-structured focus group interview held in June 2014 were managers from various enterprises with different roles, e.g. a wind park

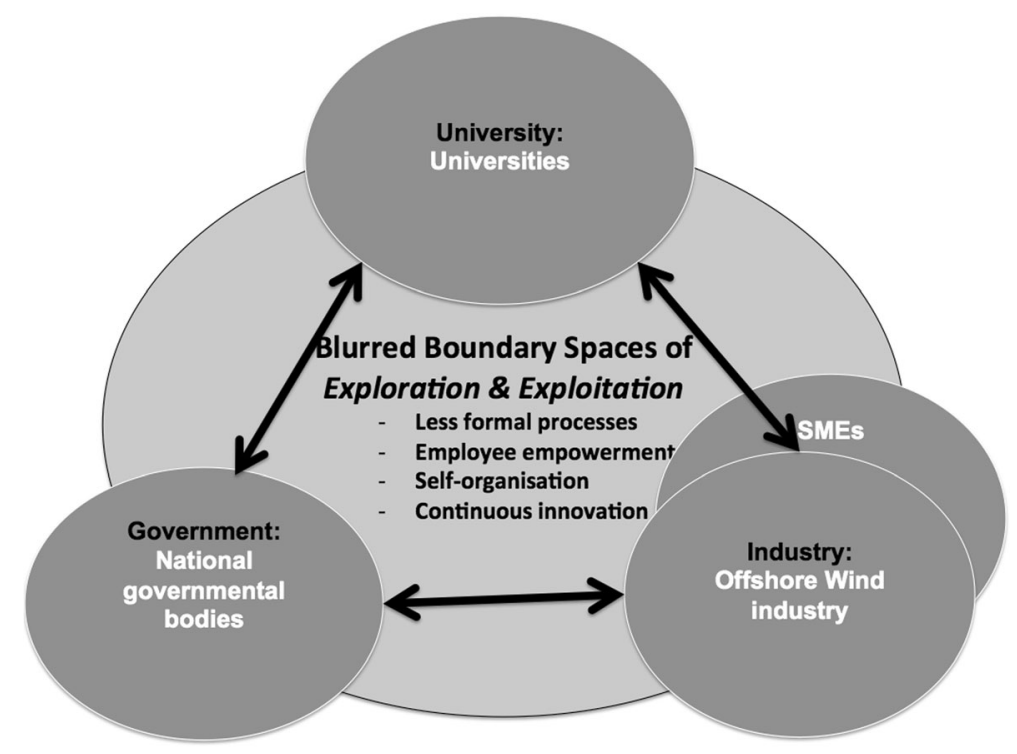

Fig. 1 Framing of proposition 1 
owner, a wind turbine producer, equipment suppliers, service providers of equipment and/ or staffing. The focus group interview was transcribed to analyse the findings (Eisenhardt 1989; Yin 2009). Different roles and interests were found in the offshore wind industry for service providers offering manpower/equipment/components and service providers offering transportation/maintenance solutions using different logistic approaches.

Next, semi-structured open-ended interviews were conducted from October 2014 to March 2015 with actors from 20 additional enterprises participating in O\&M activities in offshore wind parks, including wind park owners, wind turbine producers and smalland medium-sized enterprises (SMEs). Furthermore, industry associations for suppliers to wind parks were interviewed. Through this individual interview approach, more indepth interviews could be conducted regarding the challenges and lessons learned in reducing LCOE at different offshore wind park sites. All interviewees had at least 5 years of experience working with offshore wind parks. Confidentiality was important to the majority of the interviewees, which means that citations in this article are anonymous to the reader. All interviews were recorded and transcribed for thorough analysis. In Table 1, an anonymous overview is provided on the individual interviewees regarding the role of their organisations and their own role within the enterprise.

Table 1 shows the different roles of the interviewees and the level and function in which they operate in the organisation. The information from the interviews is based on six very different roles in the offshore wind park business supplier network. Rich information drawn from different interests and roles is thus present in the data. Moreover, different management levels are also present; however, all have a connection to the O\&M field of offshore wind parks. Strategically, important issues are anticipated to be addressed by the experienced managers in the O\&M field. 'Converging lines of inquiry' (Yin 2009: 115) began to emerge on the issues for research and were prominent in the last $25 \%$ of the interviews; the interviewees highlighted predominantly the same answers to the research question as already gathered-just from different perspectives. Deductive analyses were conducted after the researchers ended the interviews in March 2015. The researchers went through all transcriptions and selected the interesting quotes regarding the proposition.

In May 2015, a follow-up seminar was held for the presentation of the preliminary findings from the research and for the representatives of the offshore wind park industry to discuss the necessary steps to reduce LCOE. Overall, 60 participants from different O\&M

Table 1 Anonymous overview of the interviewees

\begin{tabular}{|c|c|c|}
\hline Role & Level/function in the organisation & Number \\
\hline \multirow[t]{2}{*}{ Wind farm owner } & Manager — wind farm responsible & 2 \\
\hline & $\begin{array}{l}\text { Manager_O\&M/service responsible } \\
\text { for wind farms }\end{array}$ & 5 \\
\hline \multirow[t]{2}{*}{ Wind turbine producer } & Manager — wind turbine producer & 1 \\
\hline & $\begin{array}{l}\text { Manager_O\&M/service responsible } \\
\text { for wind farms }\end{array}$ & 2 \\
\hline $\begin{array}{l}\text { Service providers, manpower, } \\
\text { equipment/component suppliers }\end{array}$ & Manager_-service/supply responsible & 3 \\
\hline Logistics service providers & Manager_service/logistic responsible & 3 \\
\hline Capital partners & Manager-investment responsible & 2 \\
\hline Industry associations & Manager & 2 \\
\hline Total interviewees & & 20 \\
\hline
\end{tabular}


actors provided a foundation for comments on the preliminary findings, and a discussion thus unfolded. The presentations and discussions afterwards were recorded for analysis, which could supplement and triangulate the findings for LCOE reduction. A summarised report from the research is available on the website of the Danish Wind Association for own wind industry interpretation (Brink et al. 2015).

\section{Wind ecosystem networks in general-the specific focus of the research}

Offshore wind parks are power plants on the sea that produce electricity from renewable source wind. The electricity is generated through wind turbines and converted into electricity with the aid of transformer platforms and cables. Offshore wind farms are created through complex construction projects, and each location is unique due to different wind, weather and soil conditions (EWEA 2015; WEC 2013). Moreover, the lifetime of offshore wind farms is characterised by different phases that are considered somewhat in isolation in relation to each other, e.g. construction, production, installation and O\&M; however, considerable spill-over is present between phases and can therefore be viewed as network systems (Houman et al. 2014; Autio and Thomas 2014).

The first offshore wind farm was established in 1991 in Vindeby in Denmark, and since then, the number of farms has increased rapidly, particularly in Northern Europe. By the end of 2015, 84 wind farms had been built with a total capacity of 11,027.3 MW and a cross total of 3230 wind turbines situated in 11 European countries with enough electricity production to cover 1.5\% of the EU's total electricity consumption (EWEA 2015). Installed capacity is highest in the UK with $46 \%$, followed by Germany with 30\%, Denmark with $12 \%$ and the rest of the countries have less than $10 \%$ of installed capacity each. The North Sea alone has 70\% of the installed offshore wind capacity, followed by the Irish Sea with 18\% and the Baltic Sea with 12\%. The largest wind park owner/developer is DONG with 16\% of installed capacity, followed by E.ON with 10\%, RWE Innogy with 9\%, Vattenfall with nearly $9 \%$ and the rest of the wind farm owners have less than $5 \%$ each of the installed capacity. The wind turbine is the largest component in the offshore wind farms, and the market share of wind turbine manufacturers (original equipment manufacturers (OEMs)) are, respectively, Siemens with $64 \%$ of total installed capacity, MHI Vestas with 19\% and the rest of the wind turbine manufacturers with less than $10 \%$ each of installed capacity of offshore wind in Europe (EWEA, 2015). Through these numbers, it can be revealed that the offshore wind park industry consists of dominating actors both regarding wind turbine manufacturers (original equipment manufacturers (OEMs)) and in relation to wind farm owners/developers (utilities/energy providers). The domination is strongest at the OEM level, where the enterprises are focused on production of the turbine components and the service of those components for typically $3-5$ years after installation. The turnover of these large OEMs is typically split into nearly equal parts regarding production and service. The market shares on installed capacity are important antecedents for O\&M activities in offshore wind parks as the service contracts are based on installed capacity. None of the wind farm owners/developers are so large that they can dominate the market alone.

In pace with renewable forms of energy production winning terrain, offshore wind parks are under pressure to reduce LCOE so that offshore wind energy can be considered a competitive alternative among non-renewable energy sources (Crown Estate 2012). Offshore wind energy is currently $2-3$ times as expensive measured by LCOE as onshore wind energy and other traditional energy sources (OpenEI 2016; WEC 2013). 
For the time being, electricity produced in offshore wind parks is therefore subsidised by governments, and although LCOE from offshore wind farms had decreased by $11 \%$ during the 2010-2014 period, extended efforts are needed to reach the target of producing competitive offshore wind energy of approximately $£ 100 / \mathrm{MWh}$ by 2020 (Catapult 2015) and the target set by the GWEC (2016) to reduce LCOE to 80 EUR/MWh in 2025. Recently, a surprising result from a tender completed in November 2016 at Kriegers Flak (600 MW Danish offshore wind farm in the Baltic Sea) was won by Vattenfall at 49.9 EUR/MWh (Vattenfall, 2016). It shows that one of the wind farm owners/developers anticipates considerable opportunities for innovation in the offshore ecosystem to reduce LCOE, which has the potential to resonate in the market and create demands for the organising of innovation collaboration in the ecosystem.

The long-term constant pressure to reduce LCOE has resulted in offshore wind farms with longer distances to the coast to achieve better wind conditions (Crown Estate, 2012). As a consequence, the companies in this relatively young industry continuously face new demands for innovative product, process and business model solutions.

\section{Operation and maintenance (O\&M) of offshore wind farms}

O\&M activities can be conducted by the wind farm owner or can be outsourced to other enterprises through service contracts. Moreover, maintenance can occur either as scheduled maintenance (necessary to replace/adjust components/functions regularly in the offshore wind park) or as unscheduled maintenance (equipment/components/functions that unexpectedly break down in the offshore wind park). Both scheduled and unscheduled maintenance can be done by the wind farm owner or outsourced to other enterprises in a service contract. When the O\&M work is outsourced in scheduled/unscheduled service context, independent service providers perform the service for the wind farm owner. A number of different roles thus coexist in O\&M in offshore wind parks, including wind park owners, equipment/component suppliers and different service providers of components and logistics regarding manpower, equipment and maritime services.

The O\&M phase is characterised by Houman et al. (2014; p. 56) as a phase undertaken by dominating actors, and they refer to this by stating the following:

O\&M today is to a great extent an exclusive market, where wind turbine producers and energy providers so far define the regime of the collaboration.

The dominating role of OEMs is related to the fact that the installation of wind turbines is followed by a guarantee period (typically $3-5$ years), during which the OEMs are usually responsible for the O\&M activities. In other words, a few large OEMs dominate the market, e.g. Siemens and MHI Vestas, together with a few less dominating larger utilities, e.g. DONG Energy, Vattenfall and E.ON. However, a large amount of small- and mediumsized enterprises (SMEs) participate in the offshore wind park industry (VMI and Deloitte 2014). This typically means a blend of relatively few larger actors and many SMEs that perform activities on wind parks, from construction and installation to O\&M. These independent service providers (ISPs) can be divided into two main categories. One of the categories is concerned with the maritime logistics to and from the offshore wind farms, and the other is focused on providing technically qualified manpower and equipment to undertake O\&M-related activities. After the guarantee period, the wind park owner is 
likely to take over the O\&M, and thereafter, these activities are typically undertaken by the wind park owner himself and/or outsourced to the ISPs. For the time being, the O\&M market is primarily oligopolistic (Siemens and MHI Vestas), often with restricted opportunities for SMEs to participate. The main objective of the O\&M activities is to ensure that the turbines run as smoothly as possible and have high performance in terms of electricity production during the lifetime operation. It provides higher yield for return on investments (Crown Estate 2012). The early wind parks could be reached quickly by using boats originally used for fishing, and the few technically relatively simple wind turbines were easy to access and maintain. However, these operations have gained increasing complexity, as with more remote locations, the logistics and the efficiency and effectiveness of O\&M activities become very important. Additionally, more remote distances also mean that it is crucial to design logistic solutions, which, on the one hand, can ensure safe access to the turbines despite strong wind and high waves and, on the other hand, bring the employees to and from the site more quickly, either from the coast or from the accommodation ships or platforms situated at sea. Combinations of crew transport vessels (CTV), service operation vessels (SOV), jack-ups and helicopters are thus needed.

\section{Funding and ownership of wind parks}

The primary investors in offshore wind parks have traditionally been power producers (utilities) who use their balance sheets by re-financing existing projects through debt (project-financed bank debt or project bonds) or by selling equity (EWEA 2013). Through joint ventures with other power producers or third-party capital funds/institutional investors, power producers have enhanced their opportunities for financing further offshore wind parks and, thus, have enhanced their own business. Currently, investors from Engineering, Procurement, Installation and Construction companies (EPIC), wind turbine manufacturers (OEMs), oil and gas (O\&G) enterprises and corporate investors are investing in offshore wind energy (EWEA 2013), e.g. Siemens has invested in the wind park Butendiek (Siemens and Butendiek 2013).

Power producers (utilities) typically have a long-term interest in wind parks both in technical terms and in terms of commercial interests relating to their business and to the return on investment obtained from the offshore wind park. Experience related to return on investment in offshore wind parks materialises in the O\&M phase, where the electricity produced is sold to the market. Commercial experience thus typically lags behind the technical solutions offered in wind parks. Regulatory risk related to conflicting political support for offshore wind, which results in uncertainties in grid-connecting regimes, the long-term stability of markets and changes in the conditions of the regulatory framework, is a key concern for third-party capital (EWEA 2013), as their interests are focused on securing return on investment for their own investors. Other investors in wind parks can have a combined short-term interest in their business performance and longterm interest in the return on investment of wind parks. The governance of wind parks is therefore driven by both technical and commercial business performance and by shortterm and long-term considerations and the perception of uncertainty by many involved parties during lifetime of the wind park. Uncertainty and risk are thus increasing the finance costs and cause prices of components and services to increase due to the risk, which have to be taken by the actors. 


\section{Findings}

The interviewees are in different ways involved in conducting the actual work on offshore wind parks. Therefore, both practical and more strategic issues are expected to emerge from the interviews on necessary initiatives to enable innovation in the offshore wind innovation ecosystem. The citations can support the understanding and show the important patterns. The citations are selected based on their ability to represent typical answers formulated by the interviewees. The needed initiatives are addressed according to each triple helix participant in the following:

\section{Governments: governmental bodies}

The issues stressed by the interviewees for governmental bodies to make contributions to innovation and the reduction of LCOE are cited below. First, different legal issues are mentioned:

N20: 'It would be a very good idea if the national laws could be aligned across different countries, e.g., in country A, you have to make inspections of service lifts 4 times a year, whereas in country B, one inspection every second year is sufficient... and it's possible that the service lift has not been used since the last inspection. You don't respond to the concrete problem but concentrate on following the law and that doesn't reduce LCOE.'

This response highlights both the need for antecedent alignment of laws across national boundaries and the need to frame the laws' flexibility in accordance with the actual need locally. Alignment of the regulatory framework across countries is highlighted as beneficial by the interviewees for innovation and reduction of LCOE, which means that the decreased 'formality of processes' highlighted in the literature is not actually strictly addressed. Instead, more formal and aligned processes with flexible options according to local relevance of work are needed. This transcends the current legislation across countries and call for relevance. The request for alignment is extended to the utilities/clients with an overall fit of practices to transcend the different enterprise processes.

N10: 'Try to think about this situation: yesterday, we worked in country A on a turbine from company $\mathrm{X}$; today, we work in country $\mathrm{B}$ on a turbine from company $\mathrm{Y}$; and tomorrow, we will work in country $\mathrm{C}$ on a turbine from company $\mathrm{Z}$ - the same type of jobs to be performed, but companies require a company-specific way to do the work ... And this can be combined with country-specific differences... harmonising doesn't exist.'

Enabling innovation in the offshore wind ecosystem thus requires both transcending national and organisational frames and processes. The exploitation of standards is emphasised for the flexible alignment of the regulatory framework across nations and larger enterprises.

Moreover, the EU law on tendering, which actually does transcend national and organisational frames, is perceived as too strict regarding 'arm's length'-thinking-particularly when close collaborations between ecosystem actors are needed, as highlighted in the following citation:

N9: 'The power supply companies are included in the EU tender law. We (the subcontractor) could go to a turbine producer and - in cooperation with them - develop 
new services. This is not permitted according to EU legislation, as it is viewed as disturbing 'arms' length'.

The EU tender law is thus perceived to hamper ecosystem innovation collaboration. Arm's length independence is perceived by the legal authorities/governmental bodies as more important than close explorative collaboration in solving the ecosystem challenge on innovation. Complementary capabilities are often needed in the offshore wind innovation ecosystem, and they can be employed in explorative collaboration activities between different organisations. In short, the alignment of a flexible regulatory framework needs to be enhanced by legal opportunities for explorative collaboration initiatives among enterprises to enable innovation and reduction of LCOE.

Time is an important factor that needs to be considered to achieve technically and commercially efficient and effective offshore wind parks, as stressed in the following citation:

N5: '... the new park was designed for $750 \mathrm{KW}$ turbines, but the processing times of the public authorities took nearly 10 years; in the meantime, new turbines were developed, and the park was provided with 2.3 MW turbines. The consequences of this is a park where the turbines are placed too close to each other - which causes increased LCOE.'

According to this respondent, the technical development in the industry has overtaken the approval processes by governmental bodies. When innovation challenges in innovation systems are high, a natural need for aligned timing of the processes between the triple helix parties is requested.

Additionally, 'local content' plays an important role, as illustrated in the citations below:

N5: 'In developing the new park, we decided at an early time to place the O\&M activities in country A, as we already had a setup in this country. The park was owned by 2 energy-producing companies - one in country A and the other in country B. The politicians in country B argued for placing activities in their country (B) - although costs increase.'

N5: 'If you want to do business in this country (C), you have to organise some local activities - local content. An understanding of this is important to get the orders.'

These citations stress the typical transnational ownership of offshore wind parks with the aim to reduce LCOE as conflicting the national interests of employment. A transparent open negotiation of local collaboration practices is called for to explore and exploit viable solutions to these conflicting interests, which often at the end of the day transcends pure regional/national interests.

In summary, the findings highlight a need for governmental bodies to explore and exploit the development of

- an aligned and flexible regulatory framework;

- a focus of the helices on timing, transparency and open collaboration practices. 
Proposition 1 is hereby overall supported and extended to more specific initiatives needed by the governmental bodies for balanced exploration and exploitation initiatives.

\section{Industry: offshore wind industry actors}

The issues stressed by the interviewees on industrial innovation initiatives are cited below. First, initiatives conducted with the other two helixes are mentioned.

N18: 'There are many initiatives, and it's a big advantage for the industry. One of them is the Carbon Trust consisting of, among others, 9 energy companies and partly financed by the English department of energy and climate change.'

N14: 'The industry has chosen that GWO (Global Wind Organization) has to develop minimum standards for practical training, so the different companies agree on the same level of practical training. GWO presents some overall practical standards. The starting point for the work is the international STCW (Standards of Training, Certification and Watchkeeping for Seafarers) convention applied to the maritime sector.'

Here, both the collaboration with governmental bodies (N18) and the need for collaboration with educational bodies (N14) on selection and specification of practices and exploitation according to minimum standards are noted for transparent development.

The need for enhanced collaboration in the industry context is highlighted in the following citation:

N19: 'Even if company $\mathrm{X}$ is big, they are very happy to cooperate with us (SME) on the development of new and cheaper foundations for the wind turbine. We are project managers. A technological institution is also a partner delivering specific knowledge to the project. The project is financed by the EU.'

These citations show that larger enterprises typically focus on their own core activities. Collaboration across these core activities can be supported and extended by SMEs through their 'dynamic complementarity' and a loosely coupled helix approach to easily and meaningfully transfer of knowledge through activities funded by governmental bodies. The approach provides flexibility and more certainty on the basically uncertain new innovative activities as the most proficient people with the most advanced knowledge on the specific initiatives participate.

Additionally, complementary knowledge is needed to prevent 'too early standardisation' of processes in the industry, as stressed by the interviewees, which would cause costly repair and maintenance activities as shown in the following citation:

N9: 'You can be a little worried when energy company A talks about industrialising and standardising the products and processes, as we now have to change all the (specific component) in the turbines. It is problematic to standardise products not fully developed.'

This citation stresses that too much exploitation through standards too early can hamper the offshore wind innovation ecosystem's ability to reduce LCOE. More 
emphasis on transparent exploration is needed to prevent standardisation too early to cause too much rework.

In summary, the findings in the offshore wind ecosystem industry highlight a need for industrial actors to both develop explorative and exploitative initiatives related to the following:

- Enhanced focus of the helixes on transparency and open collaboration practices;

- Utilisation of SME complementarity within innovation initiatives.

Proposition 1 is thus supported and extended to more specific needed initiatives by the industry actors for balanced exploration and exploitation initiatives.

\section{University: universities and other educational bodies}

The issues stressed by the interviewees for universities and other educational bodies are cited below. First, the research issues are mentioned:

N5: 'In relation to the Ph.D. project in O\&M, we have established a reference group, and at the last meeting, we found out it's the first time research is being conducted at the university level on O\&M. In addition, the Ph.D. student has established many interesting contacts.'

Here, the interviewee underpins the need for research at the university level to explore new knowledge and to exploit existing knowledge. Although this is expected, the interviewee surprisingly also underpins a secondary impact of research on new interesting contacts, which would not have been established without the research conducted. It supports both exploration and exploitation of knowledge through global interaction between universities, industry actors and governmental bodies creating new valuable contacts and new knowledge for reduction of LCOE.

Second, several educational issues concerning collaboration between helixes are mentioned below:

N3: 'We cannot use the services from the local technical school at all. They have to use up-to-date equipment in the teaching situation. We discussed the problem with them and decided to try to find a solution. However, they did not have 2 million DKK to invest in modern equipment. We entered into an agreement so that the technical school could use our equipment. It is an advantage for all parties...'

N13 'Ten years ago, an education program for servicemen was introduced. In the beginning, many problems were related to the qualifications of the candidates.

Collaboration and discussions among partners have meant that the problems have been identified and solved.'

As highlighted, there is a need for collaboration between the helixes in both the educational content and funding of educational equipment. This is noted in citation (N3) as a win-win situation to collaborate on educational programs. However, as highlighted by citation (N13), it seems to be troublesome and takes time, but it is a necessity for the industrial actors to have access to educational facilities and programmes. 
When complex O\&M work tasks have to be conducted on an offshore wind park, there is a need for coordination of the enterprises and the offshore projects for successful project deliveries. Here, extended education and funding are needed, as the following citation highlights:

N9: 'There is a need for some coordinating enterprises for O\&M tasks, as we perceive it. There is a need for capital funds, which can merge enterprises to larger entities. Many SMEs cannot take command and consider how the coordination can be done for service tasks on the offshore wind park. There is a difference between service above water and service under water. Service above water - any 'tractor mechanic' can work that out. Service under water requires divers and special education with several enhanced tasks.'

This citation emphasises the coordinated approach to both explore and exploit project deliveries, educational activities and work project contracts.

In summary, the findings highlight a need for universities and other educational bodies to develop both explorative and exploitative initiatives regarding the following:

- Focus of the helices on timing and open collaboration practices;

- Research and educational collaboration.

Proposition 1 is hereby supported and extended to more specific needed initiatives by the industry actors for a balanced development of explorative and exploitative initiatives.

Overall, proposition 1 is supported and extended by suggestions for more specific initiatives.

Proposition 1: the collaboration of triple helix actors in the offshore wind innovation ecosystem can use both exploration and exploitation to enhance innovation

All three triple helix actors can in conjunction support innovation collaboration.

Summary: a model to enable innovation in the offshore wind ecosystem

The issues highlighted by the interviewees are summarised in Fig. 2.

Figure 2 emphasises the need for blurred boundaries between the triple helix participants to support both exploration and exploitation in the offshore wind innovation ecosystem. The important issues are flexible alignment of the regulatory framework for support of both arms' length and collaborative practices. Next, a focus of the helixes on timing, transparency and open collaboration practices is needed. The complementarity of SME innovation dynamics can be used in conjunction with university research and educational collaboration to join forces to enable innovation in the offshore ecosystem. These issues are, to some extent, ambiguous, and to some extent, they overlap. Hereby, the ambidextrous capacity of the innovation ecosystem is stressed for a more thorough understanding and insight for policy, educational and research initiatives to support the overall aim.

\section{Conclusion and recommendation}

The research in this paper reveals how organising the innovation ecosystem can enable the achievement of the aim for innovation and competitiveness of offshore wind energy. 


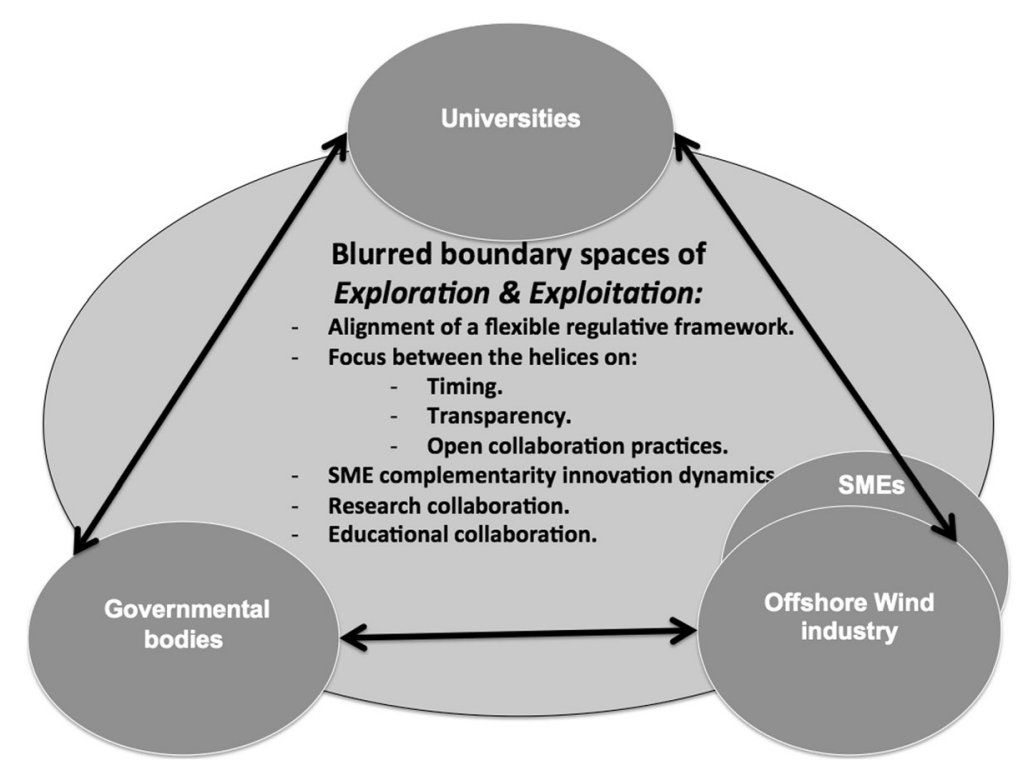

Fig. 2 The triple helix frame for innovation in the offshore wind ecosystem

The research was conducted from June 2014 to May 2015 using a qualitative deductive approach in the ecosystem context of O\&M actors in offshore wind parks. The data for the research originated from a focus group interview with 11 participants in June 2014, 20 individual interviews conducted from October 2014 to March 2015 and a follow-up seminar on the preliminary findings in May 2015.

The findings reveal opportunities for a triple helix framing of the innovation ecosystem to make a beneficial contribution and on enabling innovation and reduction of LCOE. The findings highlight the need for flexible alignment of regulations and procedures across nations and organisations. Then, a focus between the helixes is emphasised on timeliness, transparency and open collaboration practices. Additionally, SMEs can enable complementary dynamic knowledge for innovation, and university research can create new knowledge and new contacts. Moreover, collaboration with universities on both research content and funding can disseminate knowledge in the ecosystem.

The article hereby makes a contribution through the developed model on insight and understanding for the triple helix actors to enable innovation in the offshore wind ecosystem. The model summarises the findings on the specified beneficial initiatives needed in the innovation ecosystem. Recommendations are outlined and highlighted through the findings on a thorough and open transnational collaboration among the triple helix actors around the North Sea and related offshore wind ecosystems such as the offshore wind ecosystem in the Irish Sea and the Baltic Sea. At the end of the day, the same recommendations can be present globally-reaching for offshore wind ecosystems in Asia and the USA. Larger offshore wind enterprises are present globally-probably with the same needed recommendations, although the wind, weather and waterbed conditions and available local SMEs in the offshore ecosystem are different around the world. In the findings, larger enterprises and SMEs addressed the same initiatives for LCOE reduction. The closer triple helix collaboration can thus seem to contribute to more certainty for investors as opportunities in the new initiatives can be utilised through participation of the most proficient actors. 
The research conducted in this article is focused on the perception of needs seen from the industry-enterprise perspective. This lens provides only a limited view of the innovation ecosystem. However, this view provides close insight on the perceived innovation challenges, according to the actual work conducted on offshore wind parks. A point of origin is thus formed from the research for further research to look through the lens of the governmental bodies and universities.

Other ecosystem contexts could probably need other collaboration initiatives. This can be revealed through further research in different innovation ecosystem contexts. Meanwhile, the research conducted in this paper can make a suggestion on important issues developed in the offshore wind ecosystem. In particular, an overlap could be present with other renewable energy sources-requiring long-term innovation collaboration among actors.

The triple helix approach has been revealed as helpful. However, troublesome issues have also been highlighted, e.g. the long time span before the collaboration actually works and the lack of timing between helix actors. A trade-off must be anticipated between the benefits of triple helix collaboration in the innovation ecosystem and the additional time and extra costs compiled through collaboration efforts. Therefore, the triple helix concept will likely be the most useful in larger ecosystems with high requests for innovation.

\title{
Additional file
}

Additional file 1: Translation of the abstract into Arabic. (PDF $183 \mathrm{~kb}$ )

\begin{abstract}
Acknowledgements
The author would like to thank the many offshore wind farm actors contributing anonymous to this article, the Region of South Denmark for their financial assistance, the Danish Wind Industry Association in combination with offshoreenergy.dk for their administrative assistance and last but not least my former colleague, now retired, Associate Professor Svend Ole Madsen, University of Southern Denmark and former Post Doc. Salla Lutz for ideas and collaboration during research.
\end{abstract}

Competing interests

The author declares that he has no competing interests.

Received: 1 July 2016 Accepted: 24 January 2017

Published online: 24 February 2017

References

Adner R, Kapoor R (2010) Value creation in innovation ecosystems: how the structure of technological interdependence affects firm performance in new technology generations. Strateg Manag J 31:306-339

Autio E, Thomas LDW (2014) Innovation ecosystems_implications for innovation management? In: Dodgson M, Cann DM, Philips N (eds) The Oxford Handbook of Innovation Management, vol 11, Chapter. Oxford University Press, Oxford, pp 204-229

Crown Estate (2012). Offshore wind cost reduction pathways study. http://www.thecrownestate.co.uk/media/5493/eioffshore-wind-cost-reduction-pathways-study.pdf. Accessed 2 Feb 2017

Brink T, Madsen SO, Lutz S (2015). Perspectives on how operation \& maintenance (O\&M) innovations contribute to the reduction of levelized cost of energy (LCOE) in offshore wind parks. Danish Wind Industry Association - link: http:// ipaper.ipapercms.dk/Windpower/OWDrapport. Accessed 2 Feb 2017

Brink T, Madsen SO (2016) The triple helix frame for small- and medium-sized enterprises for innovation and development of offshore wind energy, 3(4) 1-23. Open acces link, viewed 19. June 2016: http://triplehelixjournal.springeropen.com/ articles/10.1186/s40604-016-0035-8

Dodgson M (2014) Collaboration and innovation management. In: Dodgson M, Gann DM, Philips N (eds) The Oxford Handbook of Innovation, vol Chapter 23. Oxford University Press, Oxford, pp 462-48

DWIA (Danish Wind Industry Association) (2012). Danish wind turbine industry statistics - http://ipaper.ipapercms.dk/ Windpower/Branchestatistik/Branchestatistik2012/. Accessed 2 Feb 2017

Eisenhardt KM (1989) Building theories from case study research. Acad Manage Rev 14(4):532-550

EAWE (European Academy of Wind Energy) (2016). Long-term research challenges in wind energy-a research agenda by the European Academy of Wind Energy. http://www.wind-energ-sci.net/1/1/2016/wes-1-1-2016.pdf. Accessed 2 Feb 2017 
Etzkowitz H, Leydesdorff $L$ (2000) The dynamics of innovation: from National Systems and "Mode 2" to a Triple Helix of university-industry-government relations. Res Policy 29:109-125

Etzkowitz H, Viale R (2010) Polyvalent knowledge and the entrepreneurial university: a third academic revolution? Crit Sociol 36(4):595-609

Etzkowitz H (2014) The entrepreneurial university wave: from ivory tower to global economic engine. Ind High Educ 28(4):223-232

European Commission, Fact Sheet (2015). http://ec.europa.eu/priorities/energy-union/index_en.htm. Accessed 2 Feb 2017

EWEA Report (2013) Where is the money coming from? Financing offshore wind parks. http://www.ewea.org/ fileadmin/files/library/publications/reports/Financing_Offshore_Wind_Farms.pdf. Accessed 2 Feb 2017

EWEA (2015). The European Offshore Wind Industry Key Trends and Statistics 2015. http://www.ewea.org/fileadmin/ files/ibrary/publications/statistics/EWEA-European-Offshore-Statistics-2015.pdf. Accessed 2 Feb 2017

GWEC (2016) Global Wind Energy Council - Declaration. http://www.gwec.net/wp-content/uploads/2016/06/160603FINAL-Offshore-wind-cost-reduction-statement-with-annex.pdf. Accessed 2 Feb 2017

Houman Andersen P, Drejer I, Gjerding AN (2014). Offshore vindenergi I Danmark. Niche eller ny industry? Institut for $\varnothing$ konomi og Ledelse, Aalborg Universitet

IRENA (2016) Global Atlas for Renewable Energy. International Renewable Energy Agency (IRENA). http://irena.masdar. ac.ae. Accessed 2 Feb 2017

Leydesdorff L (2012) The Triple Helix. ..., an N-tuple Helices: explanatory models for analyzing the knowledge-based economy? J Knowl Econ 3(1):25-35

Leydesdorff L, Meyer M (2006) Triple Helix indicators of knowledge-based innovation systems. Res Policy 35 (10):1441-1449

Malerba F, Adams P (2014) Sectoral systems of innovation. In: Dodgson M, Gann DM, Philips N (eds) The Oxford Handbook of Innovation, vol Chapter 10. Oxford University Press, Oxford, pp 183-203

Offshore Renewable Energy Catapult (2015) Cost reduction monitoring framework. Summary report to the Offshore Wind Programme Board. https://ore.catapult.org.uk/wp-content/uploads/2016/05/CRMF-ORE-Catapult-report-to-theOWPB.pdf. Accessed 2 Feb 2017

Open El (2016) viewed 19 June 2016, http://en.openei.org/apps/TCDB/index.php?pMin=2009\&pMax=2012\&dMin= 2009\&dMax =2012\&gf=h\&dol=0\&|=n\&t=|coe\&ct=bDOE\%20-\%20US\%20Department\%20of\%20Energy. Accessed 2 Feb 2017

Porter M (1998) Clusters and the new economics of competition. Harv Bus Rev 76(76):77-90

Rothwell R, Dodgson M (1991) External linkages and innovation in small and medium-sized firms. R\&D Manag 21(2): 125-162

Siemens and Butendiek, (2013) Weblink. http://finance.siemens.com/financialservices/gloe.bal/en/references/ documents/butendiek-offshore_en.pdf. Accessed 2 Feb 2017

Steiber A, Alänge S (2015) Organizational innovation: verifying a comprehensive model for catalysing organisational development and change. Triple Helix 2:14

United Nations (UN) (2015). General assembly—-transforming our world: the 2030 agenda for sustainable development. A/RES/70/1. Retrieved from https://sustainabledevelopment.un.org/post2015/transformingourworld/publication. Accessed 2 Feb 2017

Vattenfall press release (2016) Vattenfall wins tender to build the largest wind farm in the Nordics. https://corporate. vattenfall.com/press-and-media/press-releases/2016/vattenfall-wins-tender-to-build-the-largest-wind-farm-in-thenordics/. Accessed 2 Feb 2017

VMI and Deloitte (2014) Analyse af leverandører til vindindustrien - markedsudvikling 2013. https://www2.deloitte.com/ content/dam/Deloitte/dk/Documents/financial-services/Analyse-vindmøllebranchen-2014-Deloitte.pdf. Accessed 2 Feb 2017.

World Energy Council (WEC) (2013). World energy perspective. https://www.worldenergy.org/wp-content/uploads/ 2013/09/WEC J1143_CostofTECHNOLOGIES_021013_WEB Final.pdf. Accessed 2 Feb 2017

Yin RK (2009). Case study research: design and methods. Sage. Applied Social Research Methods and series 5 , Washington DC

\section{Submit your manuscript to a SpringerOpen ${ }^{\circ}$ journal and benefit from:}

- Convenient online submission

- Rigorous peer review

- Immediate publication on acceptance

- Open access: articles freely available online

- High visibility within the field

- Retaining the copyright to your article 